\title{
PERBANDINGAN KADAR TRIGLISERIDA PADA OBES 1 DAN OBES 2
}

\author{
Inri A. H. Oway \\ Sonny J. R. Kalangi \\ Taufik Pasiak
}

\begin{abstract}
Bagian Anatomi-Histologi Fakultas Kedokteran Universitas Sam Ratulangi Manado
Email: inri14_star@yahoo.com
\end{abstract}

\begin{abstract}
Background. Triglycerides are a type of fat that can be found in blood which are stored the most in human body. Triglycerides are used as an energy source for various metabolic processes. High levels of triglycerides can lead to various health problems. Elevated triglycerides levels can be caused by various things, such as obesity. Obesity results when fat accumulates in body. Obesity and elevated triglycerides levels can affect human health. Objective. The aim for this research was to compare triglyceride levels of obese 1 and obese 2 students of Faculty of Medicine Sam Ratulangi University. Method. An observational method with cross sectional design research was done to compare triglyceride levels in obese 1 and obese 2 students of Faculty of Medicine Sam Ratulangi University academic year 2010 and 2011. In the number of 49 people, (30 people were obese 1 and 19 people were obese 2). The data were analyzed using SPSS, test of hypothesis used Mann Whitney. Result. The mean values of triglyceride levels in obese 1 students were $69,00 \mathrm{mg} / \mathrm{dL}$ and in obese 2 students were $85,53 \mathrm{mg} / \mathrm{dL}$. Conclusion. There were significant differences on triglyceride levels in obese 1 and obese 2 .
\end{abstract}

Keyword: fat, obesity, triglyceride.

\begin{abstract}
Abstrak. Latar Belakang. Trigliserida merupakan jenis lemak yang paling banyak pada tubuh manusia dan dapat ditemukan dalam darah. Trigliserida berguna sebagai sumber energi untuk berbagai proses metabolik tubuh. Akan tetapi jika kadar trigliserida terlalu tinggi maka dapat menimbulkan berbagai masalah kesehatan. Peningkatan kadar trigliserida dapat disebabkan oleh berbagai hal, salah satunya karena obesitas. Obesitas terjadi karena peningkatan akumulasi lemak dalam tubuh. Obesitas dan peningkatan kadar trigliserida dapat mempengaruhi tingkat kesehatan seseorang. Tujuan. Penelitian ini bertujuan untuk membandingkan kadar trigliserida pada mahasiswa obes 1 dan obes 2 Angkatan 2010 dan 2011 di Fakultas Kedokteran Universitas Sam Ratulangi. Metode. Penelitian ini dilakukan dengan metode observasional dan desain studi cross sectional untuk membandingkan kadar trigliserida pada mahasiswa obes 1 dan obes 2 Angkatan 2010 dan 2011 di Fakultas Kedokteran Universitas Sam Ratulangi. Jumlah sampel pada penelitian ini sebanyak 49 orang yang terdiri dari 30 orang obes 1 dan 19 orang obes 2. Analisis data dilakukan dengan menggunakan SPSS dan uji hipotesis menggunakan Uji Mann-Whitney. Hasil. Kadar trigliserida rata-rata pada obes 1 sebesar $69,00 \mathrm{mg} / \mathrm{dL}$ dan kadar trigliserida rata-rata pada obes 2 sebesar 85,53 mg/dL. Kesimpulan. Secara statistik terdapat perbedaan bermakna kadar trigliserida pada obes 1 dan obes 2 .
\end{abstract}

Kata Kunci: lemak, obesitas, trigliserida. 
Obesitas merupakan suatu penyakit multifaktorial, yang terjadi akibat akumulasi jaringan lemak berlebihan, sehingga dapat mengganggu kesehatan. Obesitas terjadi bila besar dan jumlah sel lemak bertambah pada tubuh seseorang. Bila seseorang bertambah berat badannya maka ukuran sel lemak akan bertambah besar dan kemudian jumlahnya bertambah banyak. ${ }^{1}$

Pada penelitian yang dilakukan di 12 kota di Asia, menunjukkan bahwa angka kejadian obesitas mengalami peningkatan (lebih dari 23\%). ${ }^{2}$ Pada periode tahun 20092010, lebih dari 35\% warga Amerika Serikat mengalami obesitas. Tidak ada perbedaan signifikan antara angka kejadian obesitas pada wanita maupun pria. ${ }^{3}$

Prevalensi obesitas berhubungan dengan urbanisasi dan mudahnya mendapatkan makanan serta banyaknya jumlah makanan yang tersedia. Urbanisasi dan perubahan status ekonomi yang terjadi di negara-negara yang sedang berkembang berdampak pada peningkatan prevalensi obesitas pada populasi di negara-negara ini, termasuk Indonesia. ${ }^{1}$ Data prevalensi obesitas di Indonesia tercatat sebanyak 19,1\% pada tahun 2007. ${ }^{4}$ Berdasarkan data dari National Health and Nutrition Examination Survey (NHANES) orang obesitas dengan Indeks Massa Tubuh (IMT) >30 pada usia lebih dari 20 tahun, prevalensinya meningkat setiap tahunnya. Pada periode 1988-1994 didapatkan data orang obesitas dengan IMT >30 sebesar 22,9\% dan pada periode tahun 2007-2008 diperoleh data orang obesitas dengan IMT $>30$ sebesar $33,8 \%$. $^{5}$

IMT merupakan indikator yang paling sering digunakan dan praktis untuk mengukur tingkat populasi berat badan lebih dan obesitas pada orang dewasa. Untuk penelitian epidemiologi digunakan IMT atau Indeks Quetelet, yaitu berat badan dalam kilogram (kg) dibagi tinggi dalam meter kuadrat $\left(\mathrm{m}^{2}\right)$. Saat ini IMT merupakan indikator yang paling bermanfaat untuk menentukkan berat badan lebih atau obesitas. ${ }^{1}$

Trigliserida adalah ester trihidrat alkohol gliserol dan asam lemak. ${ }^{6}$ Sejauh ini lemak yang paling banyak dalam diet yaitu lemak netral yang dikenal sebagai trigliserida, yang setiap molekulnya tersusun dari sebuah inti gliserol dan rantai samping tiga asam lemak. Lemak netral merupakan unsur utama dalam bahan makanan yang berasal dari hewan dan sangat sedikit ada dalam makanan yang berasal dari tumbuhan. ${ }^{7}$ Trigliserida biasanya meningkat pada keadaan obesitas dan pada penyakit diabetes tipe 2 . Peningkatan kadar trigliserida menyebabkan timbulnya gangguan pada metabolisme lemak dan sensitivitas insulin. ${ }^{8}$

Berdasarkan data diatas dan dikaitkan dengan resiko penyakit yang diakibatkan karena peningkatan trigliserida maka penulis tertarik untuk mengadakan penelitian untuk membandingkan kadar trigliserida pada orang obes 1 dan obes 2 ..

\section{METODE PENELITIAN}

Penelitian ini dilakukan dengan metode observasional dan desain studi cross sectional untuk membandingkan kadar trigliserida pada mahasiswa obes 1 dan obes 2 Angkatan 2010 dan 2011 di Fakultas Kedokteran Universitas Sam Ratulangi. Penelitian dilakukan di Fakultas Kedokteran Universitas Sam Ratulangi Manado pada bulan November-Desember 2012. Populasi pada penelitian ini yaitu semua mahasiswa Fakultas Kedokteran Angkatan 2010 dan 2011 di Universitas Sam Ratulangi Manado. Sampel yang digunakan yaitu mahasiswa dengan obes 1 dan obes 2 Angkatan 2010 dan 2011 di Fakultas Kedokteran Universitas Sam Ratulangi Manado yang di pilih sesuai dengan kriteria inklusi dan eksklusi. Kriteria inklusi yaitu mahasiswa obes 1 dengan IMT 25-29.9 dan mahasiswa obes 2 dengan IMT $\geq 30$ yang bersedia menjadi sampel dalam penelitian. Kriteria Eksklusi yaitu mahasiswa dengan tinggi badan $<150$ cm dan berusia $<18$ tahun, serta menolak untuk terlibat dalam penelitian ini. Alat dan bahan yang digunakan untuk pengukuran IMT pada penelitian ini yaitu alat tulis menulis, microtoise, timbangan digital, 
meteran dan kalkulator.

Data dikumpulkan oleh peneliti dengan melakukan pengukuran berat badan dan tinggi badan untuk menentukan IMT pada mahasiswa Angkatan 2010 dan 2011 di Fakultas Kedokteran Universitas Sam Ratulangi Manado. Dari data yang dikumpulkan dipilih mahasiswa-mahasiswa dengan obes 1 dan obes 2 yang memenuhi kriteria inklusi dan dilakukan pemeriksaan trigliserida di Laboratorium Klinik Medistar Manado. Dari data yang didapat, kemudian dilakukan pengolahan data dengan ini menggunakan analisis MannWhitney pada SPSS versi 20.

\section{HASIL PENELITIAN}

Penelitian ini dilakukan pada bulan November-Desember 2012 pada mahasiswa Fakultas Kedokteran Universitas Sam Ratulangi Manado Angkatan 2010 dan 2011. Mahasiswa angkatan 2010 berjumlah 277 orang dan mahasiswa angkatan 2011 berjumlah 310 orang. Jumlah keseluruhan mahasiswa angkatan 2010 dan 2011 yaitu sebanyak 587 orang.

Penelitian terdiri dari dua tahap, yaitu yang pertama dilakukan pengukuran berat badan dan tinggi badan untuk menentukan IMT mahasiswa dan tahap yang kedua yaitu melakukan pengukuran kadar trigliserida. Pada penelitian tahap pertama untuk menentukan IMT yang dilakukan pada mahasiswa angkatan 2010 dan 2011, terdapat 425 orang yang bersedia terlibat dalam penelitian ini, sedangkan 162 orang lainnya menolak untuk terlibat dalam penelitian ini. Dari 425 orang tersebut kemudian dilakukan pengukuran berat badan dan tinggi badan untuk menentukan nilai IMT mahasiswa (Tabel 1).

Pada penelitian ini, yang menjadi sampel penelitian yaitu mahasiswa obes 1 dan obes 2. Berdasarkan data diatas, jumlah mahasiswa obes 1 sebanyak 45 orang dan jumlah mahasiswa obes 2 sebanyak 24 orang. Pada penelitian tahap 2, hanya terdapat 49 orang mahasiswa yang sesuai dengan kriteria-kriteria yang ditentukan dan bersedia untuk terlibat dalam penelitian
Tabel 1. Hasil pengukuran indeks massa tubuh (IMT)

\begin{tabular}{lcc}
\hline \multicolumn{1}{c}{ Klasifikasi IMT } & $\begin{array}{c}\text { Angkatan } \\
\mathbf{2 0 1 0}\end{array}$ & $\begin{array}{c}\text { Angkatan } \\
\mathbf{2 0 1 1}\end{array}$ \\
\hline $\begin{array}{l}\text { Underweight } \\
\text { (IMT }<18,5)\end{array}$ & 28 Orang & 45 Orang \\
$\begin{array}{l}\text { Normal } \\
\text { IMT 18,5-22,9) }\end{array}$ & 110 Orang & 109 Orang \\
$\begin{array}{l}\text { Overweight } \\
\text { (IMT 23,0-24,9) }\end{array}$ & 37 Orang & 27 Orang \\
$\begin{array}{l}\text { Obes 1 } \\
\text { (IMT 25,0-29,9) }\end{array}$ & 26 Orang & 19 Orang \\
$\begin{array}{l}\text { Obes 2 } \\
\text { (IMT } \geq 30)\end{array}$ & 14 Orang & 10 Orang \\
\hline
\end{tabular}

ini, yang terdiri dari 30 orang mahasiswa obes 1 dan 19 orang mahasiswa obes 2 .

Berikut ini dipaparkan perincian tabel dan data deskriptifnya:

\section{Usia sampel penelitian}

Usia sampel pada penelitian ini berkisar antara usia 18-22 tahun. Di bawah ini dipaparkan mengenai usia sampel penelitian.

Tabel 2. Usia sampel penelitian

\begin{tabular}{ccccc}
\hline Obes & $\mathbf{n}^{*}$ & $\mathbf{U}^{* *}$ & $\mathbf{r}^{* * *}$ & $\mathbf{S B}^{* * * *}$ \\
\hline Obes 1 & 30 & $18-22$ & 19,37 & 0,96 \\
Obes 2 & 19 & $18-21$ & 19,63 & 0,96 \\
Total & 49 & $18-22$ & 19,47 & 0,96 \\
\hline
\end{tabular}

*n: jumlah sampel

$* * \mathrm{U}$ : usia (Tahun)

***r: rata-rata (Tahun)

****SB: simpangan baku (Tahun)

Data tabel 2 dapat dilihat bahwa untuk sampel penelitian mahasiswa obes 1 berusia antara 18-22 tahun dengan rata-rata 19,37 tahun dan simpangan baku 0,96 tahun. Untuk sampel penelitian mahasiswa obes 2 berusia antara 18-21 tahun dengan rata-rata 19,63 tahun dan simpangan baku 0,96 tahun. Secara keseluruhan, sampel dalam penelitian ini berusia antara 18-22 tahun dengan rata-rata 19,47 tahun dan simpangan baku 0,96 tahun. 


\section{Berat badan sampel penelitian}

Berat badan sampel pada penelitian ini berkisar antara 59-123 Kg. Di bawah ini dipaparkan mengenai berat badan sampel penelitian.

Tabel 3. Berat badan sampel penelitian

\begin{tabular}{lcccc}
\hline \multicolumn{1}{c}{ Obes } & $\mathbf{n}^{*}$ & $\mathbf{B B}^{* *}$ & $\mathbf{r}^{* * *}$ & $\mathbf{S B}^{* * * *}$ \\
\hline Obes 1 & 30 & $59-90$ & 74,50 & 8,41 \\
Obes 2 & 19 & $70-123$ & 89,68 & 14,69 \\
Total & 49 & $59-123$ & 80,39 & 13,40
\end{tabular}

*n: jumlah sampel

**BB: berat badan $(\mathrm{Kg})$

$* * *$ r: rata-rata $(\mathrm{Kg})$

****SB: simpangan baku (Kg)

Data tabel 3 dapat dilihat bahwa berat badan untuk sampel penelitian mahasiswa obes 1 antara 59-90 $\mathrm{Kg}$ dengan rata-rata 74,50 Kg dan simpangan baku 8,41 Kg. Untuk berat badan sampel penelitian mahasiswa obes 2 antara 70-123 $\mathrm{Kg}$ dengan rata-rata 89,68 $\mathrm{Kg}$ dan simpangan baku $14,69 \mathrm{Kg}$. Secara keseluruhan berat badan sampel penelitian ini antara 59-123 $\mathrm{Kg}$ dengan rata-rata $80,39 \mathrm{Kg}$ dan simpangan baku 13,40 Kg.

\section{Tinggi badan sampel penelitian}

Tinggi Badan sampel pada penelitian ini berkisar antara 1,52-1,79 m. Di bawah ini dipaparkan mengenai tinggi badan sampel penelitian.

Tabel 4. Tinggi badan sampel penelitian

\begin{tabular}{lcccc}
\hline \multicolumn{1}{c}{ Obes } & $\mathbf{n}^{*}$ & TB** & $\mathbf{r}^{* * *}$ & $\mathbf{S B}^{* * * *}$ \\
\hline Obes 1 & 30 & $1,52-1,79$ & 1,67 & 0,09 \\
Obes 2 & 19 & $1,52-1,79$ & 1,66 & 0,07 \\
Total & 49 & $1,52-1,79$ & 1,67 & 0,08 \\
\hline *n: jumlah sampel & & \\
**TB: Tinggi badan (m) & & \\
***: rata-rata (m) \\
****SB: simpangan baku (m)
\end{tabular}

Data tabel 4 dapat dilihat bahwa tinggi badan untuk sampel penelitian mahasiswa obes 1 antara 1,52-1,79 m dengan rata-rata 1,67 $\mathrm{m}$ dan simpangan baku 0,09 m. Untuk tinggi badan sampel penelitian mahasiswa obes 2 antara 1,52-1,79 m dengan rata-rata 1,66 m dan simpangan baku 0,07 m. Secara keseluruhan tinggi badan sampel antara 1,52-1,79 $\mathrm{m}$ dengan rata-rata $1,67 \mathrm{~m}$ dan simpangan baku 0,08 m.

\section{Indeks massa tubuh (IMT) sampel penelitian}

Nilai IMT dihitung berdasarkan berat badan (Kg) dibagi dengan tinggi badan $\left(\mathrm{m}^{2}\right)$. Nilai IMT pada sampel penelitian ini berkisar diantara 25,18-46,87. Di bawah ini dipaparkan mengenai nilai IMT pada sampel yang terlibat dalam penelitian ini.

Tabel 5. Indeks massa tubuh sampel penelitian

\begin{tabular}{lcccc}
\hline \multicolumn{1}{c}{ Obes } & n* & IMT** & r*** & SB**** \\
\hline Obes 1 & 30 & $25,18-28,73$ & 26,54 & 0,97 \\
Obes 2 & 19 & $30,10-46,87$ & 32,53 & 4,08 \\
Total & 49 & $25,18-46,87$ & 28,86 & 3,94 \\
\hline *n: jumlah sampel & & \\
**IMT: Indeks Massa Tubuh & & \\
***r: rata-rata & & \\
****SB: simpangan baku &
\end{tabular}

Data tabel 5 dapat dilihat bahwa IMT untuk sampel penelitian mahasiswa obes 1 antara 25,18-28,73 dengan rata-rata 26,54 dan simpangan baku 0,97. Untuk IMT sampel penelitian mahasiswa obes 2 antara 30,10-46,87 dengan rata-rata 32,53 dan simpangan baku 4,08. Secara keseluruhan tinggi badan sampel penelitian ini antara 25,18-46,87 dengan rata-rata 28,86 dan simpangan baku 3,94.

\section{Kadar trigliserida sampel penelitian}

Kadar trigliserida sampel pada penelitian ini berkisar antara 32-132 mg/dL. Di bawah ini dipaparkan mengenai tinggi badan sampel penelitian.

Data tabel 6 dapat dilihat bahwa kadar trigliserida untuk sampel penelitian mahasiswa obes 1 antara 36-131 mg/dL dengan rata-rata $69,00 \mathrm{mg} / \mathrm{dL}$ dan simpangan baku 23,23 mg/dL. Untuk kadar trigliserida mahasiswa obes 2 antara 32-132 $\mathrm{mg} / \mathrm{dL}$ dengan rata-rata $85,53 \mathrm{mg} / \mathrm{dL}$ dan 
Tabel 6. Kadar trigliserida sampel penelitian

\begin{tabular}{lcccc}
\hline \multicolumn{1}{c}{ Obes } & $\mathbf{n}^{*}$ & TG** & $\mathbf{r}^{* * *}$ & SB $^{* * * *}$ \\
\hline Obes 1 & 30 & $36-131$ & 69,00 & 23,23 \\
Obes 2 & 19 & $32-132$ & 85,53 & 29,82 \\
Total & 49 & $32-132$ & 75,41 & 26,94 \\
\hline *n: jumlah sampel & & \\
**TG: kadar trigliserida (mg/dL) \\
***r: rata-rata (mg/dL) \\
****SB: simpangan baku (mg/dL)
\end{tabular}

simpangan baku 29,82 mg/dL. Secara keseluruhan kadar trigliserida pada sampel penelitian ini antara 32-132 $\mathrm{mg} / \mathrm{dL}$ dengan rata-rata $75,41 \mathrm{mg} / \mathrm{dL}$ dan simpangan baku $26,94 \mathrm{mg} / \mathrm{dL}$.

\section{Analisis Mann-Whitney untuk memban- dingkan kadar trigliserida pada Obes 1 dan Obes 2}

Tujuan utama dari penelitian ini yaitu untuk melihat perbandingan kadar trigliserida pada obes 1 dan obes 2. Pada penelitian ini terdapat dua hipotesis, yaitu: $\mathrm{H}_{0}$; Tidak terdapat perbedaan kadar trigliserida pada obes 1 dan obes $2, \mathrm{H}_{\mathrm{a}}$; Terdapat perbedaan kadar trigliserida pada obes 1 dan obes 2

Metode yang dipilih untuk menguji hipotesis yang ada, yaitu metode MannWhitney menggunakan SPSS versi 20. Untuk kriteria bermakna dari suatu penelitian dipenuhi apabila nilai sig $<\alpha(\alpha=0,05)$. Berdasarkan analisis yang dilakukan diperoleh nilai significance sebesar 0,041. Hal ini menunjukkan bahwa hipotesis alternatif (Ha) diterima dan hipotesis nol $\left(\mathrm{H}_{0}\right)$ ditolak.

\section{PEMBAHASAN}

Trigliserida adalah bentuk kimia dari sebagian besar lemak yang terdapat di dalam makanan maupun di dalam tubuh. Trigliserida dalam plasma berasal dari lemak dalam makanan yang dimakan atau di buat di dalam tubuh yang berasal dari karbohidrat. Kalori yang berasal dari makanan yang tidak segera digunakan akan dikonversi menjadi trigliserida dan akan di bawa sekaligus disimpan di jaringan lemak. ${ }^{9}$

Trigliserida dipakai dalam tubuh terutama untuk menyediakan energi bagi berbagai proses metabolik. Akan tetapi, beberapa lipid, terutama kolesterol, fosfolipid dan sejumlah kecil trigliserida dipakai untuk membentuk semua membran sel dan untuk melakukan fungsi-fungsi sel yang lain.

Peningkatan kadar trigliserida disebut dengan hipertrigliseridemia. ${ }^{9}$ Banyak hal yang dapat menyebabkan terjadinya peningkatan kadar trigliserida, misalnya berkaitan dengan penyakit diabetes, sindrom metabolik, obesitas, hipotiroid, konsumsi alkohol berlebihan dan sindrom nefrotik. ${ }^{10}$

Pada penelitian ini dibahas mengenai trigliserida dan kaitannya dengan obesitas. Penelitian ini lebih menekankan pada perbandingan kadar trigliserida pada obes 1 dan obes 2 dengan menggunakan sampel mahasiswa angkatan 2010 dan 2011 di Fakultas Kedokteran Universitas Sam Ratulangi Manado.

Obesitas mengacu pada peningkatan lemak tubuh. ${ }^{11}$ Pada penelitian ini terdapat 49 orang yang bersedia berpartisipasi sebagai sampel yang terdiri dari 30 orang obes 1 dan 19 orang obes 2. Pada kelompok sampel obes 1 dengan IMT antara 25,0 29,9 memiliki rata-rata berat badan 74,50 kg dan rata-rata tinggi badan 1,67 m, sedangkan pada kelompok sampel obes 2 dengan $\mathrm{IMT} \geq 30$ memiliki rata-rata berat badan 89,68 $\mathrm{kg}$ dan rata-rata tinggi badan 1,66 m (lihat tabel 3 dan 4). Dari data diatas menunjukkan bahwa kelompok sampel obes 2 memiliki nilai rata-rata berat badan yang lebih tinggi dibandingkan dengan kelompok sampel obes 1. Akan tetapi dari data tinggi badan menunjukkan bahwa kelompok sampel obes 1 memiliki nilai rata-rata yang lebih tinggi dibandingkan obes 2 .

Pada penelitian ini yang menjadi fokus utamanya yaitu berkaitan dengan perbandingan kadar trigliserida pada obes 1 dan obes 2. Dari penelitian yang telah dilakukan didapatkan hasil bahwa kelompok sampel obes 1 memiliki kadar trigliserida rata-rata sebesar 69,00 mg/dL sedangkan kelompok sampel obes 2 memiliki kadar trigliserida rata-rata sebesar 
85,53 mg/dL (lihat tabel 5). Dari data tersebut menunjukkan bahwa nilai rata-rata kadar trigliserida pada kelompok sampel obes 2 lebih tinggi dibandingkan dengan kelompok sampel obes 1.

Dari hasil analisis data yang dilakukan diperoleh hasil bahwa secara statistik terdapat perbedaan bermakna kadar trigliserida pada obes 1 dan obes 2 . Walaupun secara statisitik terdapat perbedaan bermakna antara kadar trigliserida pada obes 1 dan obes 2, tetapi jika dilihat kadar trigliserida pada masing-masing sampel pada obes 1 dan obes 2 memiliki kadar trigliserida yang masih berada pada batasan normal $(<150 \mathrm{mg} / \mathrm{dL})$.

Peningkatan kadar trigliserida sering terjadi pada orang dengan obesitas. Peningkatan kadar trigliserida juga dapat terjadi karena sindrom metabolik. Selain itu, terdapat juga beberapa keadaan lain yang berhubungan dengan peningkatan trigliserida, yaitu Diabetes tipe 2 yang tidak terkontrol, hipotiroid, penyakit hati, penyakit Ginjal, faktor genetik dan efek samping dari pengobatan, yaitu penggunaan obatobat beta-blocker, pengobatan dengan steroid dan diuretik, pil $K B$, serta tomoxifen. $^{12}$

Berdasarkan penelitian yang dilakukan di Universitas Göteborg, Swedia, hasilnya menunjukkan bahwa peningkatan kadar trigliserida pada orang dengan obesitas berkaitan dengan terjadinya dual metabolic defect, yaitu peningkatan sekresi dan gangguan pengeluaran dari triglyceriderich VLDL1. ${ }^{13}$

Berdasarkan data dari International Diabetes Federation, angka kejadian sindrom metabolik lebih banyak terjadi pada usia 80-89 tahun yaitu sebesar $47 \%$ pada pria dan $64 \%$ pada wanita, sedangkan untuk usia 20-29 tahun hanya sebesar 11\% untuk pria dan $9 \%$ untuk wanita. ${ }^{14}$

Berdasarkan data diatas dapat terlihat bahwa obesitas pada seseorang tidak dapat dijadikan sebagai satu-satunya acuan untuk menentukkan tinggi rendahnya kadar trigliserida pada orang tersebut, melainkan perlu diperhatikan juga hal-hal lain yang dapat menyebabkan peningkatan kadar trigliserida yang salah satunya berkaitan dengan gangguan metabolik yang terjadi. Prevalensi gangguan metabolik terbanyak pada usia diatas 80 tahun, sedangkan pada usia kurang dari 20 tahun angka kejadiannya jarang terjadi. Hal tersebut dapat menguatkan hasil penelitian yang didapat bahwa kadar trigliserida pada sampel yang digunakan masih berada pada batasan normal, karena usia sampel masih di bawah 23 tahun.

Pada penelitian ini pengambilan sampel hanya didasarkan pada keadaan obesitas saja dan tidak melibatkan hal-hal lain yang dapat berpengaruh pada peningkatan kadar trigliserida. Sehingga keadaan ini berpengaruh pada hasil dari kadar trigliserida yang ukur, karena nilai trigliserida yang didapat masih berada dalam kisaran nilai normal.

\section{SIMPULAN}

Berdasarkan hasil penelitian diperoleh kesimpulan bahwa secara statistik terdapat perbedaan bermakna kadar trigliserida pada obes 1 dan obes 2 . Kadar trigliserida ratarata pada obes sebesar $69,00 \mathrm{mg} / \mathrm{dL}$ dan kadar trigliserida rata-rata pada obes 2 sebesar 85,53 mg/dL. Keadaan obesitas dan peningkatan kadar trigliserida dapat menyebabkan terjadinya berbagai masalah kesehatan.

\section{UCAPAN TERIMA KASIH}

Ucapan terima kasih penguji Dr. Sunny Tjandra Wangko, dr, MSi, PHK, PA(K) dan dr. Djon Wongkar, M.Kes, AIFO, mahasiswa angkatan 2010 dan 2011 di Fakultas Kedokteran Universitas Sam Ratulangi Manado, Laboratorium Medistar Manado, dan kepada semua pihak yang baik secara langsung maupun tidak langsung telah menumbuhkan ide atau gagasan dalam pemikiran penulis serta membantu penulis dalam menyelesaikan artikel ini.

\section{DAFTAR PUSTAKA}

1. Sugondo S. Obesitas. In: Sudoyo AW, 
Setiyohadi B, Alwi I, Simandibrata M, Setiati S, editors. Buku Ajar Ilmu Penyakit Dalam. Jilid III (Edisi Kelima). Jakarta: Interna Publishing, 2010.

2. Tee ES. Obesity in Asia: prevalence and issue in assessment methodologies. Asia Pasifik J Clin Nutr. 2002;11(3):694-701.

3. Ogden CL, Carroll MD, Kit BK, Flegal KM. Prevalence of Obesity in United States, 2009-2010. NCHS Data Brief. 2012;(82).

4. Retnaningsih E. Prediksi prevalensi obesitas pada penduduk umur diatas 15 tahun di Indonesia. Jurnal Pembangunan Manusia. 2010;10(1).

5. Ogden CL, Carroll MD. Prevalence of Overweight, Obesity, and Extreme Obesity Among Adults: United States, Trends 1960-1962 Through 2007-2008. 2010. [cited October 25, 2012]. Available from: www.cdc.gov/nchs/data/hestat/obesity_adu lt_07_08.pdf.

6. Murray RK, Granner DK, Rodwell VW. Biokimia Harper (Edisi ke-27). Jakarta: EGC; 2009.

7. Guyton AC, Hall JE. Buku Ajar Fisiologi Kedokteran (Edisi Kesebelas). Jakarta: EGC; 2007.

8. Li WD, Dong C, Li D, Garrigan C, Price RA. A Genome scan for serum triglycerides in obese nuclear family. Journal of Lipid Research. 2005;46
9. American Heart Asociation. Triglycerides [homepage on the Internet]. 2012 [cited 2012 Sep 27]. Available from: http://www.heart.org/HEARTORG/Getting Healthy/NutritionCenter/Triglycerides_UC M_306029_Article.jsp.

10. Moll J. What are High Triglycerides? [homepage on the Internet]. 2012 [cited 2012 Oct 20]. Available from: cholesterol.about.com/cs/lipoproteintypes/a /triglycerides.htm.

11. Bray GA. The Metabolic Syndrome and Obesity. New Jersey: Humana Press; 2007.

12. DeWitt RC. How to Lower High Triglycerides [homepage on the Internet]. 2008 [cited 2012 Sep 27]. Available from: cholesterol.about.com/lw/Health-

Medicine/Conditions-and-disease/How-toLower-High-Triglycerides.htm

13. Fox S. High Triglycerides in Obesity: Dual Metabolic Defect? [homepage on the Internet]. 2011 [cited 2012 Sep 27]. Available from: www.theheart.org/article/ 1258111.do

14. Hidrum B, Mykletun A, Hole T, Midthjell K, Dahl AA. Age Spesifik Prevalence of the Metabolic Syndrome Defined by the International Diabetes Federation and the National Cholesterol Education Program: the Norwegian HUNT 2 Study. BMC Public Health. 2007;7:220. 